\title{
ANALISIS PENGARUH KUALITAS PELAYANAN DAN LOKASI TERHADAP KEPUASAN PASIEN DI PUSKESMAS DUKUN GRESIK
}

\author{
*(Akhlis Priya Pambudy \\ Prodi Manajemen, Fakultas Ekonomi, Universitas Islam Lamongan \\ $\mathrm{Jl}$. Veteran No.53A Lamongan \\ Telp. ( 0322 ) 324706, Faks. ( 0322 ) 324706 \\ Email :jpim.unisla@gmail.com
}

\begin{abstract}
ABSTRAK
Penelitian ini merupakan jenis penelitian kuantitatif pada Puskesmas Dukun Gresik. Menganalisis pengaruh variabel kualitas pelayanan $\left(X_{1}\right)$ dan lokasi $\left(X_{2}\right)$ terhadap kepuasan pasien $(Y)$. Diajukan hipotesis bahwa variabel kualitas pelayanan $\left(X_{1}\right)$ dan lokasi $\left(\mathrm{X}_{2}\right)$ berpengaruh secara parsial dan simultan, serta diduga variabel kualitas pelayanan $\left(X_{1}\right)$ berpengaruh paling dominan terhadap kepuasan pasien. Metode penelitian ini menggunakan penelitian kuantitatif dan penghitungan uji validitas, uji reabilitas, analisis regresi linear berganda, analisis korelasi ganda, koefisien determinasi, uji $t$ dan uji F. Dari hasil penelitian disimpulkan bahwa, kualitas pelayanan dan lokasi mempunyai pengaruh yang signifikan terhadap kepuasan pasien, dan variable kualitas pelayanan $\left(X_{1}\right)$ berpengaruh paling dominan terhadap kepuasan pasien di puskesmas Dukun Gresik.
\end{abstract}

Kata kunci: kualitas pelayanan, lokasi, kepuasan pasien

\section{PENDAHULUAN}

Manusia adalah faktor kunci keberhasilan dari suatu pembangunan. Untuk menciptakan manusia yang berkualitas diperlukan suatu derajat kesehatan manusia yang prima sehingga dalam hal ini mutlak diperlukan pembangunan kesehatan. Untuk mendukung pencapaian pembangunan kesehatan pemerintah telah menyediakan beberapa sarana/fasilitas kesehatan beserta tenaga kesehatannya. Salah satu fasilitas kesehatan yang banyak dimanfaatkan masyarakat adalah Puskesmas. Sebagai ujung tombak pelayanan dan pembangunan kesehatan di Indonesia maka Puskesmas perlu mendapatkan perhatian terutama berkaitan dengan mutu pelayanan kesehatan Puskesmas sehingga dalam hal ini Puskesmas terlebih pada Puskesmas yang dilengkapi dengan unit rawat inap dituntut untuk selalu meningkatkan keprofesionalan dari para pegawainya serta meningkatkan fasilitas/sarana kesehatannya untuk memberikan kepuasan kepada masyarakat pengguna jasa layanan kesehatan. Kesehatan merupakan suatu kebutuhan yang sangat penting. Kebutuhan disini adalah kebutuhan untuk mendapatkan pelayanan kesehatan.

Namun, sampai saat ini usaha pemerintah dalam memenuhi kebutuhan masyarakat akan kesehatan masih belum dapat memenuhi harapan masyarakat. Banyak anggota masyarakat yang mengeluh dan merasa tidak puas dengan pelayanan yang diberikan oleh Puskesmas milik pemerintah ini baik itu dari segi pemeriksaan yang kurang diperhatikan oleh petugas kesehatan, 
lama waktu pelayanan, keterampilan petugas, sarana/fasilitas, serta waktu tunggu untuk mendapatkan pelayanan.

Pusat Kesehatan Masyarakat (PUSKESMAS) sebagai salah satu sarana kesehatan yang memberikan pelayanan kesehatan kepada masyarakat memiliki peran yang sangat strategis dalam mempercepat peningkatan derajat kesehatan masyarakat.

Oleh karena itu Puskesmas dituntut untuk memberikan pelayanan yang bermutu yang memuaskan bagi pasiennya sesuai dengan standar yang ditetapkan dan dapat menjangkau seluruh lapisan masyarakatnya.

Salah satu keluhan yang sering terdengar dari masyarakat yang berhubungan dengan aparatur pemerintah adalah selain berbelit-belit akibat birokrasi yang kaku, perilaku oknum aparatur yang kadang kala kurang bersahabat, juga kinerja pegawai dalam memberikan pelayanan dalam hal ini ketepatan waktu dalam memberikan pelayanan, kuantitas dan kualitas pelayanan yang masih sangat rendah.

Rendahnya kinerja pelayanan akan membangun citra buruk pada Puskesmas, dimana pasien yang merasa tidak puas akan menceritakan kepada rekan-rekannya. Begitu juga sebaliknya, semakin tinggi kinerja pelayanan yang diberikan akan menjadi nilai plus bagi Puskesmas, dalam hal ini pasien akan merasa puas terhadap pelayanan yang diberikan oleh Puskesmas.

Puskesmas dapat mengetahui kinerja pelayanan dari para pasien melalui umpan balik yang diberikan pasien kepada Puskesmas tersebut sehingga dapat menjadi masukan untuk peningkatan kinerja pelayanan

Menurut Fandy Tjiptono (2005) Kualitas merupakan suatu kondisi dinamis yang berpengaruh dengan produk, jasa, manusia, proses dan lingkungan yang memenuhi atau melebihi harapan. Sehingga definisi kualitas pelayanan dapat diartikan sebagai upaya pemenuhan kebutuhan dan keinginan konsumen serta ketepatan penyampaiannya dalam mengimbangi harapan konsumen.

Menurut Kotler (2002) definisi pelayanan adalah setiap tindakan atau kegiatan yang dapat ditawarkan oleh suatu pihak kepada pihak lain, yang pada dasarnya tidak berwujud dan tidak mengakibatkan kepemilikan apapun. Produksinya dapat dikaitkan atau tidak dikaitkan pada satu produk fisik. Pelayanan merupakan perilaku produsen dalam rangka memenuhi kebutuhan dan keinginan konsumen demi tercapainya kepuasan pada konsumen itu sendiri.

Kotler juga mengatakan bahwa perilaku tersebut dapat terjadi pada saat, sebelum dan sesudah terjadinya transaksi. Pada umumnya pelayanan yang berkualitas tinggi akan menghasilkan kepuasan yang tinggi serta pembelian ulang yang lebih sering.

Menurut Fandy Tjiptono dan Gregorius Chandra (2005) Secara garis besar, ada dua kemungkinan pertimbangan dalam hal lokasi fasilitas jasa. Pertama, pelanggan mendatangi lokasi fasilitas jasa dan yang kedua adalah penyedia jasa yang mendatangi pelanggan. Selain itu penyedia jasa dimungkinkan mengkombinasikan keduanya. Jika perusahaan berhasil memperoleh dan mempertahankan lokasi yang strategis, maka itu dapat menjadi rintangan yang efektif bagi para pesaing untuk mendapatkan akses ke pasar.

Rumusan masalah dalam penelitian ini adalah (1) Apakah kualitas pelayanan dan lokasi berpengaruh secara parsial terhadap 
kepuasan pasien di puskesmas Dukun Gresik? (2) Apakah kualitas pelayanan dan lokasi berpengaruh secara simultan terhadap kepuasan pasien di puskesmas Dukun Gresik? (3) Dari kedua variabel diatas (kualitas pelayanan dan lokasi) variabel mana yang berpengaruh paling dominan terhadap kepuasan pasien di puskesmas Dukun Gresik?

Berdasarkan perumusan masalah di atas, tujuan penelitiannya adalah : (1) Untuk mengetahui apakah kualitas pelayanan dan lokasi berpengaruh secara parsial terhadap kepuasan pasien di puskesmas Dukun Gresik. (2) Untuk mengetahui apakah kualitas pelayanan dan lokasi berpengaruh secara simultan terhadap kepuasan pasien di puskesmas Dukun Gresik. (3) Untuk mengetahui kedua variabel (kualitas pelayanan dan lokasi ) yang berpengaruh paling dominan terhadap kepuasan pasien di puskesmas Dukun Gresik.

\section{LANDASAN TEORI}

pada rumah sakit menjelaskan bahwa indikator WHO menjelaskan bahwa perawat memiliki peran kunci untuk melaksanakan pendidikan kesehatan. Perawat perlu melakukan peran ini pada semua tatanan pelayanan, baik pada individu, keluarga, kelompok dan masyarakat. Perawat juga perlu melaksanakan peran ini pada semua tingkat pencegahan, mulai dari tingkat pencegahan primer sampai dengan tersier. Pendapat peneliti bahwa pasien yang berada dirumah sakit harus mendapatkan pendidikan kesehatan sebagai wujud peran perawat pada tingkat pencegahan sekunder maupun tersier. Pendidikan kesehatan harus dilaksanakan secara terprogram dan sesuai dengan kebutuhan pengetahuan yang mereka perlukan saat dirawat maupun ketika pulang. Discharge planning/ perencanaan pemulangan pasien adalah proses sistematis yang bertujuan menyiapkan pasien meninggalkan rumah sakit untuk melanjutkan program perawatan yang berkelanjutan dirumah atau diunit perawatan komunitas (Taylor, dkk. 1989) . Program perencanaan pemulangan pada dasarnya merupakan program pemberian pendidikan kesehatan kepada pasien yang meliputi nutrisi, aktifitas/ latihan, obat-obatan dan instruksi khusus yaitu tanda dan gejala penyakit pasien (Potter \& Perry, 2005). Pasien yang akan pulang jika dipersiapkan dengan baik, maka tidak akan mengalami hambatan dalam melanjutkan program pengobatan dan rehabilitasi, serta akan mencapai tingkat kesehatan yang lebih baik. Konsumen pelayanan kesehatan/ pasien menginginkan kepuasan pelayanan kesehatan yang berkualitas. Pada dasarnya konsep pelayanan berkualitas sebagai penilaian baik buruknya rumah sakit dapat dilihat dari empat komponen yang mempengaruhinya yaitu:

1) aspek klinik yang meliputi pelayanan dokter, perawat, dan teknis medis,

2) efisiensi dan efektifitas, yaitu pelayanan yang murah dan tepat guna,

3) keselamatan pasien, yaitu upaya perlindungan pasien dari hal yang membahayakan

keselamatan pasien

4) kepuasan pasien, yaitu tentang kenyamanan, keramahan dan kecepatan pelayanan (Lusa, 2007). 
Kepuasan pasien sebagai salah satu indicator pelayanan berkualitas harus menjadi perhatian karena berhubungan langsung dengan pengguna pelayanan kesehatan. Rumah Sakit Roemani merupakan rumah sakit yang sedang berkembang dan selalu ingin melakukan inovatifinovatif dengan cara pembenahanpembenahan demi mencapai tujuan sesuai visi misi. Selain itu dengan banyaknya rumah sakit swasta di Jawa Tengah juga merupakan alasan yang kuat untuk bersaing dalam meningkatkan pelayanan kesehatan yang berkualitas. Pelayanan keperawatan dilakukan dengan menggunakan proses keperawatan meskipun belum berjalan dengan baik. Pemberian pendidikan kesehatan pada pasien belum dilakukan secara terprogram terutama program pendidikan untuk pasien yang akan pulang. Pemberian informasi dilaksanakan bersamaan dengan pelaksanaan tindakan keperawatan, tetapi belum mencakup keseluruhan hal-hal yang seharusnya diketahui oleh pasien ketika pulang. Peneliti ingin mengetahui lebih lanjut bagaimana pengaruh pendidikan kesehatan persiapan pasien pulang terhadap kepuasan pasien tentang pelayanan keperawatan. Kepuasan pasien merupakan reaksi afeksi dan dinamis yang berhubungan dengan perasaan kenyamanan, keramahan, kecepatan pelayanan serta pemberian informasi tentang kesehatan yang dibutuhkan. Pelayanan keperawatan merupakan pelayanan utama pada suatu rumah sakit, dimana salah satu aspek pelayanan keperawatan yang dapat mempengaruhi kualitas pelayanan keperawatan dan kepuasan pasien adalah pemberian pendidikan kesehatan pada pasien. Berdasarkan uraian diatas ingin diketahui adakah pengaruh pemberian pendidikan kesehatan persiapan pasien pulang terhadap tingkat kepuasan pasien tentang pelayanan keperawatan

\section{METODE PENELITIAN}

Metode penelitian yang digunakan dalam penelitian ini adalah metode penelitian kuantitatif yaitu sebagai metode penelitian yang berlandaskan pada filsafat positivisme, digunakan untuk meneliti pada populasi atau sampel tertentu, teknik pengambilan sampel pada umumnya dilakuka secara random, pengumpulan data menggunakan instrumen penelitian, analisis data bersifat kuantitatif atau statistik dengan tujuan untuk menguji hipotesis yang telah ditetapkan (Sugiyono 2014 : 14).

Sugiyono (2012 : 80), mengemukakan bahwa populasi adalah wilayah generalisasi yang terdiri atas: obyek/subyek yang mempunyai kualitas dan karakteristik tertentu yang di tetapkan oleh peneliti untuk di pelajari dan kemudian di tarik kesimpulannya. Adapun yang menjadi populasi dalam penelitian ini adalah 50 pasien di puskesmas kecamatan Dukun Kabupaten Gresik.

Sampel adalah bagian dari jumlah dan karakteristik yang di miliki oleh populasi tersebut (Sugiyono, 2012 : 80). Karena sampel adalah bagian dari populasi maka sampel harus mempunyai karakteristik-karakteristik seperti yang di miliki oleh populasi. Karakteristik inilah yang menentukan apakah suatu sampel merupakan representatif yang baik bagi populasinya perlu di ingat oleh peneliti, bahwa karena analisa 
penelitian sesungguhnya di dasarkan pada data sampel sedangkan generalisasi atas kesimpulan penelitian di terapkan pada seluruh populasi, maka posisi sampel sangar strategis dan urgent. Karena itu dalam pengambilan sampel haruslah hati-hati dan mengikuti aturan yang ada sehingga sampel yang di ambil untuk mewakili populasi dapat representatif bagi populasinya.

\section{Metode Analisis Data}

Ghozali (2013 : 52) dalam Ningsih (2014 : 58), uji validitas di gunakan untuk mengukur sah atau valid tidaknya suatu kuesioner. Suatu kuesioner di katakan valid jika pertanyaan pada kuesioner mampu mengungkapkan sesuatu yang akan di ukur oleh kuesioner tersebut.

Ghozali, (2013 : 47) dalam Ningsih, (2014 : 61), menyatakan bahwa reliabilitas adalah alat untuk mengukur suatu kuesioner yang merupakan indikator dari variabel atau konstruk. Suatu kuesioner di katakan reliable atau handal jika jawaban seseorang terhadap pertanyaan adalah konsisten atau stabil dari waktu ke waktu.

Analisis linier berganda digunakan bila jumlah variabel independen minimal 2 Sugiyono (2011:275). $Y=$ $\mathrm{a}+\mathrm{b}_{1} \mathrm{X}_{1}+\mathrm{b}_{2} \mathrm{X}_{2}+\mathrm{e}$

Dimana :

Y : Variabel dependent (laba)

a : Konstanta

$b_{1} \quad$ : Koefisien regresi (Modal)

$\mathrm{b}_{2} \quad$ : Koefisien regresi (Penjualan)

$\mathrm{X}_{1} \quad$ : Variabel independent (modal)

$\mathrm{X}_{2}$ : Variabel independent (Penjualan)

e : Variabel pengganggu

Menurut Sunyoto, Danang. (2007) Untuk menghitung koefisien korelasi dengan korelasi parsial, dilakukan terlebih dahulu perhitungan korelasi tunggal, dengan rumus sebagai berikut:

$$
r=\frac{n \sum X Y-\left(\sum X\right)\left(\sum Y\right)}{\sqrt{\left\{n \sum X^{2}-\left(\sum X\right)^{2}\right\}\left\{n \sum Y^{2}-\left(\sum Y\right)^{2}\right\}}}
$$

Untuk melakukan uji atas hipotesa, dilakukan dengan cara uji t. Uji t digunakan untuk menguji apakah nilai koefisien korelasi dari variabel bebas (x) signifikan terhadap variabel (y),maka digunakan rumus $\mathrm{t}$ test sebagai berikut :

$t-t e s t=\frac{r \cdot \sqrt{(n-2)}}{\sqrt{\left(1-r^{2}\right.}}$

Keterangan:

$\mathrm{t}=$ test significant korelasi

$\mathrm{r} \quad=$ koefisien korelasi

$\mathrm{n} \quad=$ Jumlah periode (bulan)

$\mathrm{n}-2 \quad=$ derajat kebebasan $(\mathrm{df})$

Apabila $\mathrm{t}$ hitung $>\mathrm{t}$ tabel maka $\mathrm{Hi}$ diterima Ho ditolak, uji hipotesa diterima.

Apabila $\mathrm{t}$ hitung $<\mathrm{t}$ tabel maka $\mathrm{Hi}$ ditolak Ho diterima, uji hipotesa ditolak.

Duwi Priyatno (2012 : 122), uji F digunakan untuk menguji apakah variabel independen secara simultan berpengaruh terhadap variabel dependen.

$\mathrm{F}_{\text {hitung }}=\frac{R^{2} /(K)}{\left(1-R^{2}\right) /(n-k-1)}$

Dimana :

$\mathrm{R}^{2}=$ Koefisien Determinasi

$\mathrm{K}=$ Jumlah variabel independen

$\mathrm{N}=$ Jumlah sampel

$\mathrm{F}_{0}=\mathrm{F}$ hitung yang selanjutnya di bandingkan dengan $\mathrm{F}_{\text {tabel }}$

Dengan kreteria sebagai berikut :

$F_{\text {hitung }} \geq F_{\text {tabel }}$, maka Ho ditolak yang artinya terdapat hubungan yang signifikan antara modal usaha dan penjualan terhadab laba usaha.

$\mathrm{F}_{\text {hitung }} \leq \mathrm{F}_{\text {tabel}}$, maka Ho diterima yang artinya tidak ada hubungan yang 
signifikan antara modal usaha dan penjualan terhadab laba usaha.

\section{HASIL DAN PEMBAHASAN}

Analisis dan pembahasan yang akan di lakukan dalam penelitian ini adalah analisis pengaruh kualitas pelayanan dan lokasi terhadap kepuasan pasien di Puskesmas Dukun Gresik, serta membandingkan pengaruh dari variabel kualitas pelayanan yang lebih dominan. Dalam penelitian ini data yang di analisis diperoleh dengan menyebarkan kuesioner kepada 100 responden yang telah di tentukan.

\section{Penyebaran Kuesioner}

Sesuai dengan penetapan sampel, maka penulis menyebarkan kuesioner kepada 100 responden. Penyebaran kuesioner di lakukan kepada para pasien di Puskesmas Dukun Gresik sesuai dengan persyaratan sampel yang telah di tetapkan. Jumlah penyebaran dan pengumpulan kuesioener serta jumah jawaban kuesioner yang di olah dapat di lihat pada tabel di bawah ini:

Tabel 1.

Distribusi Kuesioner dan Pengumpulan Data

\begin{tabular}{|l|c|}
\hline \multicolumn{1}{|c|}{ Uraian } & Keterangan \\
\hline Sampel Terpilih & 100 \\
\hline Jumlah kuesioner yang di sebar & 100 \\
\hline Jumlah kuesioner yang terkumpul & 100 \\
\hline Pengisian tidak lengkap & 0 \\
\hline Jumlah kuesioner yang di olah & 100 \\
\hline Persentase & $100 \%$ \\
\hline
\end{tabular}

Sumber : Hasil Pengolahan Data Primer Tahun 2015 , diolah

\section{Metode Analisis Data}

\section{a. Uji Validitas}

Uji signifikan di lakukan dengan membandingkan nilai $r$ hitung dan $r$ tabel untuk degree of freedom $(\mathrm{df})=$ $\mathrm{n}-2$, di mana $\mathrm{n}$ adalah jumlah sampel.
Tabel 2.

Hasil Uji Validitas $\mathrm{X}_{1}$

\begin{tabular}{|c|c|c|c|c|c|}
\hline \multicolumn{6}{|c|}{ Correlations } \\
\hline & & $\mathrm{x} 1$ & $\times 2$ & $x 3$ & $x 4$ \\
\hline \multirow[t]{3}{*}{$x 1$} & $\begin{array}{l}\text { Pearson } \\
\text { Correlation }\end{array}$ & 1 & $.535^{\star \star}$ & $.530^{\star \star}$ & $.552^{\star \star}$ \\
\hline & Sig. (2-tailed) & & .000 & .000 & .000 \\
\hline & $\mathrm{N}$ & 100 & 100 & 100 & 100 \\
\hline \multirow[t]{3}{*}{$\times 2$} & $\begin{array}{l}\text { Pearson } \\
\text { Correlation }\end{array}$ & $.535^{\star \star}$ & 1 & $.565^{\star \star}$ & $.596^{\star *}$ \\
\hline & Sig. (2-tailed) & .000 & & .000 & .000 \\
\hline & $\mathrm{N}$ & 100 & 100 & 100 & 100 \\
\hline \multirow[t]{3}{*}{$x 3$} & $\begin{array}{l}\text { Pearson } \\
\text { Correlation }\end{array}$ & $.530^{* *}$ & $.565^{\star \star}$ & 1 & $.676^{\star *}$ \\
\hline & Sig. (2-tailed) & .000 & .000 & & .000 \\
\hline & $\mathrm{N}$ & 100 & 100 & 100 & 100 \\
\hline \multirow[t]{3}{*}{$\times 4$} & $\begin{array}{l}\text { Pearson } \\
\text { Correlation }\end{array}$ & $.552^{\star \star}$ & $.596^{\star \star}$ & $.676^{\text {t* }}$ & 1 \\
\hline & Sig. (2-tailed) & .000 & .000 & .000 & \\
\hline & $\mathrm{N}$ & 100 & 100 & 100 & 100 \\
\hline
\end{tabular}

Sumber : Output SPSS 17

Dari hasil uji validitas $X_{1}$ yaitu kualitas pelayanan, di dapat nilai Pearson Correlation pada masingmasing item yaitu $\mathrm{X}_{1}$ di dapat $\mathrm{r}$ hitung $0,552, X_{2}$ di dapat $r$ hitung 0,596, $\mathrm{X}_{3}$ di dapat $\mathrm{r}$ hitung 0,676 dan $\mathrm{X}_{4}$ di dapat $r$ hitung 0,676. Jika $r$ hitung $>r$ tabel maka kuesioner dinyatakan valid.

Tabel 3.

Hasil Uji Validitas $\mathrm{X}_{2}$

\begin{tabular}{|c|c|c|c|c|c|}
\hline \multicolumn{6}{|c|}{ Correlations } \\
\hline & & $\mathrm{x} 1$ & $\mathrm{x} 2$ & $\mathrm{x} 3$ & $\mathrm{x} 4$ \\
\hline \multirow[t]{3}{*}{$x 1$} & $\begin{array}{l}\text { Pearson } \\
\text { Correlation }\end{array}$ & 1 & .174 & $.462^{*}$ & $.389^{*}$ \\
\hline & $\begin{array}{l}\text { Sig. (2- } \\
\text { tailed) }\end{array}$ & & .084 & .000 & .000 \\
\hline & $\mathrm{N}$ & 100 & 100 & 100 & 100 \\
\hline \multirow[t]{3}{*}{$x^{2}$} & $\begin{array}{l}\text { Pearson } \\
\text { Correlation }\end{array}$ & .174 & 1 & $.237^{*}$ & $.453^{\prime \prime}$ \\
\hline & $\begin{array}{l}\text { Sig. (2- } \\
\text { tailed) }\end{array}$ & .084 & & .018 & .000 \\
\hline & $\mathrm{N}$ & 100 & 100 & 100 & 100 \\
\hline \multirow[t]{3}{*}{$\times 3$} & $\begin{array}{l}\text { Pearson } \\
\text { Correlation }\end{array}$ & $.462^{*}$ & $.237^{*}$ & 1 & $.491 *$ \\
\hline & $\begin{array}{l}\text { Sig. (2- } \\
\text { tailed) }\end{array}$ & .000 & .018 & & .000 \\
\hline & $\mathrm{N}$ & 100 & 100 & 100 & 100 \\
\hline \multirow[t]{3}{*}{$x^{4}$} & $\begin{array}{l}\text { Pearson } \\
\text { Correlation }\end{array}$ & $.389^{*}$ & $.453^{*}$ & $.491^{*}$ & 1 \\
\hline & $\begin{array}{l}\text { Sig. (2- } \\
\text { tailed) }\end{array}$ & .000 & .000 & .000 & \\
\hline & $\mathrm{N}$ & 100 & 100 & 100 & 100 \\
\hline \multicolumn{6}{|c|}{$\begin{array}{l}\text { **. Correlation is significant at the } 0.01 \text { level (2- } \\
\text { tailed). }\end{array}$} \\
\hline
\end{tabular}

Sumber: Output SPSS 17

Dari hasil uji validitas $X_{2}$ yaitu variabel lokasi, di dapat nilai Pearson 
Correlation pada masing-masing item yaitu $\mathrm{X}_{1}$ di dapat $\mathrm{r}$ hitung $0,389, \mathrm{X}_{2}$ di dapat $r$ hitung $0,453, X_{3}$ di dapat $r$ hitung 0,491 dan $\mathrm{X}_{4}$ di dapat $\mathrm{r}$ hitung 0,491. Jika $\mathrm{r}$ hitung $>\mathrm{r}$ tabel maka kuesioner dinyatakan valid.

Tabel 4.

Hasil Uji Validitas Y

\begin{tabular}{|c|c|c|c|c|c|}
\hline \multicolumn{6}{|c|}{ Correlations } \\
\hline & & $\mathrm{x} 1$ & $\mathrm{x} 2$ & $\mathrm{x} 3$ & $\mathrm{x} 4$ \\
\hline \multirow[t]{3}{*}{$\mathrm{x} 1$} & $\begin{array}{l}\text { Pearson } \\
\text { Correlation }\end{array}$ & 1 & $.424_{*}^{*}$ & $.563_{*}^{*}$ & $.416_{*}^{*}$ \\
\hline & $\begin{array}{l}\text { Sig. (2- } \\
\text { tailed) }\end{array}$ & & .000 & .000 & .000 \\
\hline & $\mathrm{N}$ & 100 & 100 & 100 & 100 \\
\hline \multirow[t]{3}{*}{$\mathrm{x} 2$} & $\begin{array}{l}\text { Pearson } \\
\text { Correlation }\end{array}$ & $.424_{*}^{*}$ & 1 & $.512_{*}^{*}$ & $.411_{*}^{*}$ \\
\hline & $\begin{array}{l}\text { Sig. (2- } \\
\text { tailed) }\end{array}$ & .000 & & .000 & .000 \\
\hline & $\mathrm{N}$ & 100 & 100 & 100 & 100 \\
\hline \multirow[t]{3}{*}{$\mathrm{x} 3$} & $\begin{array}{l}\text { Pearson } \\
\text { Correlation }\end{array}$ & $.563_{*}^{*}$ & $.512_{*}^{*}$ & 1 & $.569^{*}$ \\
\hline & $\begin{array}{l}\text { Sig. (2- } \\
\text { tailed) }\end{array}$ & .000 & .000 & & .000 \\
\hline & $\mathrm{N}$ & 100 & 100 & 100 & 100 \\
\hline \multirow[t]{3}{*}{$\mathrm{x} 4$} & $\begin{array}{l}\text { Pearson } \\
\text { Correlation }\end{array}$ & $.416_{*}^{*}$ & $.411_{*}^{*}$ & $.569^{*}$ & 1 \\
\hline & $\begin{array}{l}\text { Sig. (2- } \\
\text { tailed) }\end{array}$ & .000 & .000 & .000 & \\
\hline & $\mathrm{N}$ & 100 & 100 & 100 & 100 \\
\hline
\end{tabular}

Sumber : Output SPSS 17

Dari hasil uji validitas $Y$ yaitu variabel kepuasan pasien, di dapat nilai Pearson Correlation pada masing-masing item yaitu $\mathrm{Y}_{1}$ di dapat $r$ hitung $0,416, \mathrm{Y}_{2}$ di dapat $\mathrm{r}$ hitung $0,411, Y_{3}$ di dapat $r$ hitung 0,569 dan $\mathrm{Y}_{4}$ di dapat $\mathrm{r}$ hitung 0,569. Jika $\mathrm{r}$ hitung > $r$ tabel maka kuesioner dinyatakan valid.

\section{b. Uji Reliabilitas}

Reliabilitas adalah alat untuk mengukur suatu kuesioner yang merupakan indikator dari variabel atau konstruk. Suatu kuesioner di katakan reliable atau handal jika jawaban seseorang terhadap pertanyaan adalah konsisten atau stabil dari waktu ke waktu.
Tabel 5.

Hasil Uji Reliabilitas $X_{1}$

\begin{tabular}{|c|c|}
\hline \multicolumn{2}{|c|}{ Reliability Statistics } \\
\hline $\begin{array}{l}\text { Cronbach's } \\
\text { Alpha }\end{array}$ & $\mathrm{N}$ of Items \\
\hline .840 & 4 \\
\hline
\end{tabular}

Hasil pengujian reliabillitas dengan SPSS 17 metode Alpha Cronbach's di peroleh koefisien alpha Kualitas pelayanan sebesar 0,840 dari empat item pertanyaan.

Tabel 6.

Hasil Uji Reliabilitas $\mathrm{X}_{2}$

\begin{tabular}{|c|c|}
\hline \multicolumn{2}{|c|}{ Reliability Statistics } \\
\hline $\begin{array}{l}\text { Cronbach's } \\
\text { Alpha }\end{array}$ & $\mathrm{N}$ of Items \\
\hline .686 & 4 \\
\hline
\end{tabular}

Sumber: Output SPSS 17

Hasil pengujian reliabillitas dengan SPSS 17 metode Alpha Cronbach's di peroleh koefisien alpha Lokasi sebesar 0,686 dari empat item pertanyaan.

Tabel 7.

Hasil Uji Reliabilitas Y

\begin{tabular}{|c|c|}
\hline \multicolumn{2}{|c|}{ Reliability Statistics } \\
\hline $\begin{array}{l}\text { Cronbach's } \\
\text { Alpha }\end{array}$ & $\mathrm{N}$ of Items \\
\hline .774 & 4 \\
\hline
\end{tabular}

Hasil pengujian reliabillitas dengan SPSS 17 metode Alpha Cronbach's di peroleh koefisien alpha kepuasan sebesar 0,774 dari empat item pertanyaan.

Tabel 8.

Tabel Koefisien Korelasi (r)

\begin{tabular}{|c|c|c|c|}
\hline $\begin{array}{c}\text { Indikator } \\
\text { Pertanyaan }\end{array}$ & $\begin{array}{c}\text { Koefisien } \\
\text { Korelasi } \\
(\mathrm{r})\end{array}$ & $\begin{array}{c}\text { Nilai } \\
\text { Kritis }\end{array}$ & Keterangan \\
\hline $\begin{array}{c}\text { Kualitas } \\
\text { pelayanan }\end{array}$ & 0,840 & 0,6 & Reliabel \\
\hline Lokasi & 0,686 & 0,6 & Reliabel \\
\hline $\begin{array}{c}\text { Kepuasan } \\
\text { pasien }\end{array}$ & 0,774 & 0,6 & Reliabel \\
\hline
\end{tabular}

Jika lebih besar dari nilai kritis berarti instrumen reliabel. Pada taraf $\alpha$ 
$=0,05$ dan $\mathrm{n}=100$ di peroleh ternyata koefisien Alpha yang di peroleh masing-masing variabel adalah $>0,6$, yang artinya insrumen yang di gunakan Reliabel

\section{c. Uji Regresi Berganda}

Bahwa analisis regresi ganda adalah pengembangan dari analisis regresi sederhana. Kegunaannya yaitu untuk meramalkan nilai variabel terikat (Y) apabila variabel bebas minimal dua atau lebih.

Dengan berdasarkan hasil perhitungan regresi pada tabel di atas di dapatkan suatu persamaan regresi sebagai berikut:

$$
\mathrm{Y}=2,248+0,605 \mathrm{X} 1+0,205 \mathrm{X} 2
$$

Persamaan regresi dapat di jelaskan sebagai berikut :

$\mathrm{a}=2,248$, merupakan nilai konstanta yang berarti bahwa apabila variabel bebas dalam penelitian (kualitas pelayanan dan lokasi) yang mempengaruhi $=0$, maka hasil yang di peroleh dari kepuasan pasien (Y) adalah sebesar 2,248 .

$\mathrm{b}_{1}=0,605$, artinya untuk variabel kualitas pelayanan koofesien regresi $\left(b_{1}\right)$ menunjukkan nilai 0,605 yang berarti apabila variabel kualitas pelayanan mengalami kenaikan satu unit, maka kepuasan pasien akan mengalami kenaikan sebesar 0,605 pada saat variabel bebas yang lain sama dengan nol.

$b_{2}=0,205$ artinya untuk variabel lokasi koefesien regresi $\left(b_{2}\right)$ menunjukan nilai 0,205 apabila variabel lokasi mengalami kenaikan satu unit, maka kepuasan pasien akan mengalami kenaikan sebesar 0,205 pada saat variabel bebas yang lain sama dengan nol.
Dari hasil koefesien variabelvariabel bebas di atas untuk variabel yang paling dominan dilihat dari koefesien variabel bebas kualitas pelayanan dengan koefesien regresi sebesar, 0,605 mempunyai nilai terbesar di bandingkan dengan koefesien regresi variabel bebas yang lain (lokasi). Dengan demikian dapat di tarik kesimpulan bahwa faktor yang paling dominan mempengaruhi kepuasan pasien di puskesmas yaitu kualitas pelayanan.

Table 9.

\begin{tabular}{|c|c|c|c|c|c|c|c|c|c|c|}
\hline \multicolumn{11}{|c|}{ Coefficients $^{a}$} \\
\hline \multirow[b]{2}{*}{ Model } & \multicolumn{2}{|c|}{$\begin{array}{l}\text { Unstandardize } \\
\text { d Coefficients }\end{array}$} & \multirow{2}{*}{\begin{tabular}{|c|}
$\begin{array}{c}\text { Standa } \\
\text { rdized } \\
\text { Coeffici } \\
\text { ents }\end{array}$ \\
Beta
\end{tabular}} & \multirow[b]{2}{*}{$\mathrm{T}$} & \multirow[b]{2}{*}{ Sig. } & \multicolumn{3}{|c|}{ Correlations } & \multicolumn{2}{|c|}{$\begin{array}{l}\text { Collinearity } \\
\text { Statistics }\end{array}$} \\
\hline & B & $\begin{array}{l}\text { Std. } \\
\text { Error }\end{array}$ & & & & $\begin{array}{l}\text { Zero- } \\
\text { order }\end{array}$ & $\begin{array}{c}\text { Parti } \\
\text { al }\end{array}$ & Part & $\begin{array}{l}\text { Toler } \\
\text { ance }\end{array}$ & VIF \\
\hline $1 \mid \begin{array}{l}\text { (Cons } \\
\text { tant) }\end{array}$ & 2.248 & .742 & & $\begin{array}{r}3.02 \\
9\end{array}$ & .003 & & & & & \\
\hline$x 1$ & .605 & .069 & .672 & $\begin{array}{r}8.74 \\
8\end{array}$ & .000 & .813 & .664 & .498 & .550 & $\begin{array}{r}1.81 \\
9\end{array}$ \\
\hline$x 2$ & .205 & .075 & .211 & $\begin{array}{r}2.74 \\
6\end{array}$ & .007 & .661 & .269 & .156 & .550 & $\begin{array}{r}1.81 \\
9\end{array}$ \\
\hline
\end{tabular}

Table Koefisien Regresi Variabel

Sumber : Output SPSS 17

\section{d. Uji Koefesien Determinasi}

Tabel 10.

Hasil Koefesien Determinasi

\begin{tabular}{|l|c|c|c|c|c|}
\hline \multicolumn{7}{|c|}{$\begin{array}{l}\text { Mod } \\
\text { el }\end{array}$} & $\mathrm{R}$ & $\begin{array}{c}\mathrm{R} \\
\text { Squ } \\
\text { are }\end{array}$ & $\begin{array}{c}\text { Adjust } \\
\text { ed R } \\
\text { Square }\end{array}$ & $\begin{array}{c}\text { Std. Error } \\
\text { of the } \\
\text { Estimate }\end{array}$ & $\begin{array}{r}\text { Durbin- } \\
\text { Watson }\end{array}$ \\
\hline 1 & $.828^{\mathrm{a}}$ & .686 & .679 & .860 & 2.355 \\
\hline \multicolumn{7}{|l|}{ a. Predictors: (Constant), x2, x1 } \\
\hline
\end{tabular}

Sumber: Output SPSS 1

Dari tabel di atas di dapat $\mathrm{R}$ Square $=0,686$. Dari nilai tersebut dapat di tarik kesimpulan bahwa variabel kualitas pelayanan dan lokasi secara bersama-sama telah mampu menjelaskan atau menerangkan keragaman dari variabel terikat yaitu kepuasan pasien. Pengaruh variabel kualitas pelayanan dan lokasi terhadap 
kepuasan pasien memberikan kontribusi sebesar $68,6 \%$ sedangkan sisanya sebesar $31,4 \%$ di jelaskan oleh variabel bebas yang lain yang tidak di masukkan ke dalam model persamaan, misalkan faktor persaingan.

\section{e. Uji Korelasi Ganda}

Analisis korelasi berganda berfungsi untuk mencari besarnya hubungan dan kontribusi dua variabel bebas (X) atau lebih secara simultan (bersama-sama) dengan variabel terikat (Y)

Tabel 11.

Hasil Uji Korelasi Ganda

\begin{tabular}{|l|c|c|c|c|c|}
\hline \multicolumn{7}{|c|}{ Model Summary } \\
\hline $\begin{array}{l}\text { Mo } \\
\text { del }\end{array}$ & $\mathrm{R}$ & $\begin{array}{c}\mathrm{R} \\
\text { Squa } \\
\text { re }\end{array}$ & $\begin{array}{c}\text { Adjust } \\
\text { ed R } \\
\text { Square }\end{array}$ & $\begin{array}{c}\text { Std. } \\
\text { Error of } \\
\text { the } \\
\text { Estimate }\end{array}$ & $\begin{array}{c}\text { Durb } \\
\text { in- } \\
\text { Wats } \\
\text { on }\end{array}$ \\
\hline 1 & $.828^{\mathrm{a}}$ & .686 & .679 & .860 & $\begin{array}{c}2.35 \\
5\end{array}$ \\
\hline
\end{tabular}

a. Predictors: (Constant), x2, x1

b. Dependent Variable: $y$

\section{Sumber : Output SPSS 17}

Dari hasil tabel uji korelasi ganda di dapat nilai korelasi (R) sebesar 0,828. Sehingga dapat di asumsikan bahwa terjadi hubungan yang sangat kuat antara variabel kualitas pelayanan dan lokasi terhadap kepuasan pasien.

\section{f. Uji t}

Uji ini di gunakan untuk mengetahui signifikan dari pengaruh variabel independen terhadap variabel dependen secara individual dan menganggap dependen yang lain konstan.

Adapun kriteria daerah penolakan dan penerimaan hipotesis adalah:

1) Ho di tolak dan $\mathrm{H}_{\mathrm{a}}$ di terima yaitu jika $t_{\text {hitung }}>t_{\text {tabel }}$ artinya variabel bebas secara parsial mmpengaruhi variabel terikat.
2) Ho di terima dan $\mathrm{H}_{a}$ di tolak yaitu jika $t_{\text {hitung }}<t_{\text {tabel }}$ artinya variabel bebas secara parsial tidak mempengaruhi variabel terikat.

Tabel 12.

Hasil Uji t

\begin{tabular}{|c|c|c|c|c|c|c|c|c|c|c|}
\hline \multicolumn{11}{|c|}{ Coefficients $^{a}$} \\
\hline \multirow[b]{2}{*}{ Model } & \multicolumn{2}{|c|}{$\begin{array}{c}\text { Unstandard } \\
\text { ized } \\
\text { Coefficients }\end{array}$} & \multirow{2}{*}{$\begin{array}{c}\begin{array}{c}\text { Stand } \\
\text { ardiz } \\
\text { ed } \\
\text { Coeffi } \\
\text { cients }\end{array} \\
\text { Beta } \\
\end{array}$} & \multirow[b]{2}{*}{$\mathrm{t}$} & \multirow[b]{2}{*}{ Sig. } & \multicolumn{3}{|c|}{ Correlations } & \multicolumn{2}{|c|}{$\begin{array}{c}\text { Collineari } \\
\text { ty } \\
\text { Statistics }\end{array}$} \\
\hline & B & $\begin{array}{l}\text { Std. } \\
\text { Error }\end{array}$ & & & & $\begin{array}{c}\text { Zero } \\
\text { orde } \\
r\end{array}$ & $\begin{array}{l}\text { Par } \\
\text { tial } \\
\end{array}$ & $\begin{array}{c}\mathrm{Par} \\
\mathrm{t}\end{array}$ & \begin{tabular}{|c|} 
Tole \\
ranc \\
$\mathrm{e}$ \\
\end{tabular} & VIF \\
\hline \begin{tabular}{|l|l}
1 & $\begin{array}{l}\text { Co } \\
\text { nsta } \\
\text { nt) }\end{array}$ \\
\end{tabular} & $\begin{array}{r}2.24 \\
8\end{array}$ & .742 & & $\begin{array}{r}3.0 \\
29\end{array}$ & $\begin{array}{r}.00 \\
3\end{array}$ & & & & & \\
\hline $\mathrm{x} 1$ & .605 & .069 & .672 & $\begin{array}{r}8.7 \\
48 \\
\end{array}$ & $\begin{array}{r}.00 \\
0 \\
\end{array}$ & .813 & $\begin{array}{r}66 \\
4 \\
\end{array}$ & $\begin{array}{r}.49 \\
8 \\
\end{array}$ & .550 & $\begin{array}{r}1.8 \\
19 \\
\end{array}$ \\
\hline x2 & .205 & .075 & .211 & $\begin{array}{r}2.7 \\
46 \\
\end{array}$ & $\begin{array}{r}.00 \\
7 \\
\end{array}$ & .661 & $\begin{array}{r}.26 \\
9 \\
\end{array}$ & $\begin{array}{r}.15 \\
6 \\
\end{array}$ & .550 & $\begin{array}{r}1.8 \\
19 \\
\end{array}$ \\
\hline a. Depe & dent V & ariable & $e: y$ & & & & & & & \\
\hline
\end{tabular}

Dengan analisa sebagai berikut:

1) Kualitas pelayanan

Dari hasil uji $\mathrm{t}$ di peroleh nilai $\mathrm{t}$ hitung $(8,748)$ lebih besar dari pada $t$ tabel $(1,661)$, dimana t tabel di ambil menggunakan rumus $\mathrm{df}=(\mathrm{n}-\mathrm{k}-1)$ yaitu $\mathrm{df}=\quad 100-2-1=97, \quad$ sehingga menghasilkan $\mathrm{t}$ tabel 1,661. sehingga $t_{\text {hitung }}>t_{\text {tabel }}$ maka Ho di tolak yang berarti ada pengaruh yang signifikan antara variabel $\mathrm{X}_{1}$ dan variabel $\mathrm{Y}$, yang artinya bahwa ada pengaruh yang signifikan variabel kualitas pelayanan terhadap kepuasan pasien.

2) lokasi

Dari hasil uji $\mathrm{t}$ di peroleh nilai $\mathrm{t}$ hitung $(2,746)$ lebih besar dari pada $t$ tabel $(1,661)$ dimana $t$ tabel di ambil menggunakan rumus $\mathrm{df}=(\mathrm{n}-\mathrm{k}-1)$ yaitu $\mathrm{df}=\quad 100-2-1=97, \quad$ sehingga menghasilkan $t$ tabel 1,661. sehingga $t_{\text {hitung }}>t_{\text {tabel }}$ maka Ho di tolak yang berarti ada pengaruh yang signifikan antara variabel $\mathrm{X}_{2}$ dan variabel $\mathrm{Y}$, yang artinya bahwa ada pengaruh yang signifikan variabel lokasi terhadap kepuasan pasien. 


\section{g. Uji F}

Uji ini di gunakan untuk mengetahui pengaruh bersama-sama variabel bebas (independen) terhadap variabel terikat (dependen).

Tabel 13.

\begin{tabular}{|l} 
Hasil Uji F \\
\begin{tabular}{|l|l|r|r|r|c|c|}
\hline \multicolumn{7}{|c|}{ ANOVA $^{\mathbf{b}}$} \\
\hline \multicolumn{2}{|l|}{ Model } & $\begin{array}{c}\text { Sum of } \\
\text { Squares }\end{array}$ & Df & $\begin{array}{c}\text { Mean } \\
\text { Square }\end{array}$ & F & Sig. \\
\hline \multirow{2}{*}{1} & Regression & 156.447 & 2 & 78.224 & 105.762 & $.000^{\mathrm{a}}$ \\
\cline { 2 - 7 } & Residual & 71.743 & 97 & .740 & & \\
\cline { 2 - 6 } & Total & 228.190 & 99 & & & \\
\hline & a. Predictors: (Constant), x2, x1 \\
\hline
\end{tabular} b. Dependent Variable: y \\
\hline
\end{tabular}

Sumber : Output SPSS 17

Dari tabel di atas di peroleh $\mathrm{F}_{\text {hitung }}$ sebesar 105,762 sedangkan $F_{\text {tabel }}$ sebesar 2,70. dimana $F_{\text {tabel }}$ di ambil menggunakan rumus $\mathrm{df}=(\mathrm{n}-\mathrm{k}-1)$ yaitu $\mathrm{df}=\quad 100-2-1=97, \quad$ sehingga menghasilkan $F$ tabel 2,70. Karena $\mathrm{F}_{\text {hitung }}>\mathrm{F}_{\text {tabel }}$ maka Ho di tolak artinya bahwa variabel bebas (kualitas pelayanan dan lokasi) secara bersamasama mempunyai pengaruh yang signifikan terhadap kepuasan pasien.

\section{SIMPULAN DAN SARAN}

\section{A. Kesimpulan}

Berdasarkan hasil analisa dan hasil pembahasan analisa tentang kualitas pelayanan dan faktor lokasi terhadap kepuasan pasien di puskesmas Dukun Gresik di peroleh kesimpulan sebagai berikut:

1.Dari hasil uji $\mathrm{t}$ di peroleh $\mathrm{t}$ hitung kualitas pelayanan $(8,748)>\mathrm{t}$ tabel $(1,661)$ dan $t$ hitung lokasi $(2,746)$ $>\mathrm{t}$ tabel $(1,661)$. Sehingga dapat di asumsikan bahwa kedua variabel bebas mempunyai pengaruh yang signifikan terhadap kepuasan pasien.

2.Dari tabel anova di peroleh $\mathrm{F}_{\text {hitung }}$ sebesar 105,762 sedangkan $F_{\text {tabel }}$ sebesar 2,70. Karena $F_{\text {hitung }}>F_{\text {tabel }}$ maka Ho di terima artinya bahwa variabel bebas (kualitas pelayanan dan lokasi) secara bersama-sama mempunyai pengaruh yang signifikan terhadap kepuasan pasien. 3.Persamaan regresi berganda : $\mathrm{Y}=$ $2,248+0,605 \mathrm{X}_{1}+0,205 \mathrm{X}_{2}+\mathrm{e}$.

Variabel bebas yang paling dominan mempengaruhi kepuasan pasien adalah variabel kualitas pelayanan. Koefesien regresi sebesar 0,605 yang berarti apabila variabel kualitas pelayanan mengalami kenaikan satu tingkat, maka kepuasan pasien akan mengalami kenaikan sebesar 0,605 pada saat variabel bebas yang lain sama dengan nol.

\section{B. Saran}

Adapun saran yang dapat di kemukakan penulis sehubugan dengan penelitian ini adalah sebagai berikut:

1.Puskesmas hendaknya mempertahankan sistem pelayanan yang di berikan oleh petugas terhadap pasien di puskesmas. Karena puskesmas belum mengetahui tingkat kepuasan pasien. Sehingga dengan begitu puskesmas akan siap dan mampu melayani pasien untuk mempertahankan kualitas pelayanannya, karena sesuai dari hasil penelitian yang menyatakan kualitas pelayanan berpengaruh paling dominan terhadap kepuasan pasien.

2.Bagi para pasien yang ingin berobat di puskesmas hendaknya mempunyai gambaran bahwa puskesmas memberikan kualitas pelayanan yang baik sehingga tidak ragu-ragu lagi jika ingin berobat di puskesmas.

3.Dari hasil penelitian yang menunjukkan bahwa kualitas pelayanan berpengaruh paling dominan terhadap kepuasan pasien di puskesmas, hendaknya juga memberikan gambaran kepada penulis agar tidak ragu-ragu untuk berobat di puskesmas.

4.Dari hasil penelitian yang di lakukan oleh penulis, hasil yang di peroleh 


$$
\begin{aligned}
& \text { dapat membantu para pembaca } \\
& \text { sedikitnya memberikan referensi } \\
& \text { maupun informasi mengenai } \\
& \text { pemilihan puskesmas yang tepat } \\
& \text { untuk berobat dan mengecek } \\
& \text { kesehatannya. }
\end{aligned}
$$

\section{DAFTAR PUSTAKA}

Tjiptono, Fandy, 2004, Pemasaran Jasa, Malang: Bayumedia.

Alma, buchari. 2002. Manjemen pemasaran dan pemasaran jasa. Bandung: Alfabeta.

Arikunto, suharsimi, 2002. Prosedur penelitian suatu pendekatan praktik. Jakarta : Rieke cipta

Kotler, Philip. 2005. Manjemen pemasaran. Edisi kesebelas. (jilid 1) terjemah. Jakarta : Indeks.

Sugiyono, 2007. Statistik untuk penelitian. Bandung : Alfabeta.

Sugiyono, 2009. Penelitian pendidikan (pendektan kuantitatif, kualitatif, dan $R \&$ $D$. Bandung Alfabeta

Tjiptono, fandi. 2004. Strategi pemasaran. Edisi ketujuh. Jakarta : Erlangga.

Lupiyoadi, Rambat \& A Hamdani, 2006. Manajemen Pemasaran Jasa, Jakarta ; Salemba Empat

Tjiptono Fandy, Manajemen Jasa, Yogyakarta, Andy Offsiet

Stanton, William J. 2001 Prinsip Pemasaran, Jakarta Erlangga 